Boise State University

ScholarWorks

$10-2018$

\title{
Effects of Cultivation on Tuber and Starch Granule Morphometrics of Solanum jamesii and Implications for Interpretation of the Archaeological Record
}

\author{
Nicole M. Herzog \\ Boise State University \\ Lisbeth A. Louderback \\ National HIstory Museum of Utah \\ Bruce M. Pavlik \\ Red Butte Garden and Arboretum
}

\section{Publication Information}

Herzog, Nicole M.; Louderback, Lisbeth A.; and Pavlik, Bruce M. (2018). "Effects of Cultivation on Tuber and Starch Granule Morphometrics of Solanum jamesii and Implications for Interpretation of the Archaeological Record". Journal of Archaeological Science, 98, 1-6. https://doi.org/10.1016/ j.jas.2018.07.014

This is an author-produced, peer-reviewed version of this article. (c) 2018, Elsevier. Licensed under the Creative Commons Attribution-NonCommercial-NoDerivertives 4.0. The final, definitive version of this document can be found online at Journal of Archaeological Science, doi: 10.1016/j.jas.2018.07.014 


\section{EFFECTS OF CULTIVATION ON TUBER AND STARCH GRANULE MORPHOMETRICS OF SOLANUM} JAMESII AND IMPLICATIONS FOR INTERPRETATION OF THE ARCHAEOLOGICAL RECORD

Nicole M. Herzog ${ }^{1,2}$, Lisbeth A. Louderback ${ }^{2}$ and Bruce M. Pavlik ${ }^{3}$

${ }^{1}$ Department of Anthropology, Boise State University, 1910 University Dr., HEMG 116, Boise, ID 83725, USA

${ }^{2}$ Natural History Museum of Utah, Anthropology Department, University of Utah, 301 Wakara Way, Salt Lake City, Utah 84108 USA

${ }^{3}$ Conservation Department, Red Butte Garden and Arboretum, University of Utah, 300 Wakara Way, Salt Lake City, Utah 84108 USA

Corresponding author: Nicole M. Herzog, nicoleherzog@boisestate.edu 


\section{KEYWORDS}

Geophytes; starch granule analysis; plant domestication; Colorado Plateau; Four Corners potato

\section{INTRODUCTION}

Plant domestication and its processes, antecedents, and outcomes have been central themes in archaeological research for the last century. The outcome of the domestication process is a genetically modified strain of a target species that is generally more productive, easier to harvest or process, resistant to environmental stressors and/or more palatable in accordance with human preferences. Possessing such distinctive characteristics often allows domesticates to be readily distinguished from their progenitors but the steps leading to domestication (selective harvest, deliberate seed dispersal, active plant management, i.e. cultivation) can be difficult to detect archaeologically.

Researchers investigating the origins of New World domesticates have examined the evolutionary stages of domestication (see Meyer and Prugganan 2013) by applying various techniques across a range of cultivated and/or domesticated species. One approach examines the morphological and morphometric modifications of seed coat thickness and seed size (e.g. Asch and Asch, 1985; Bruno and Whitehead, 2003; Fritz and Smith, 1988; Fritz et al., 2009; Heiser Jr, 1985; Smith, 2006a, 2006b), others analyze the underlying genetic structure of a genus or species for alterations related to favorable traits (e.g. Blackman et al., 2011; Doebley et al., 2006; Harter et al., 2004; Sanjur et al., 2002; Van Heerwaarden et al., 2011; Kraft et al., 2014; Hardigan et al., 2017; for a review see: Zeder et al., 2006), and less frequently, archaeobotanists study changes in subcellular inclusions, such as sclerids/phytoliths and starch granules (e.g. Ball et al., 2016; Holst et al., 2007; Liu et al. 2015; Perry, 2002; Piperno et al., 2009) to detect human selection and intervention.

Changes in phytolith size related to cultivation have been documented in both maize and Cucurbita spp. (Pearsall, 1978; Piperno and Stothert, 2003; Piperno et al., 2009). However, geophytes often lack numerous or distinctive phytoliths. Starch granules on the other hand are 
abundant in many of the underground storage organs (such as tubers, corms, rhizomes, etc.) of geophytes, and can exhibit genus-and sometimes species-specific morphological and morphometric variability. Starch granule analysis has been used as a tool to detect the presence or absence of plant species known to have been cultivated and/or domesticated (e.g.: Dickau et al., 2007; Perry et al., 2007; Piperno and Dillehay, 2008; Zarrillo et al., 2008). In such cases, the wild progenitors and first phenotypes are either not examined or wholly unknown so that early stages of the domestication process remain obscure. But we do not know how granules respond to cultivation, in part because comparative approaches using wild progenitors are lacking. Furthermore, detecting changes in granule morphology must be statistically based, examining hundreds of starch granules from multiple plants and populations of a species to distinguish developmental variations from genetic variations (Louderback et al., 2016). This in fact may be the greatest constraint on using starch granule analysis to detect domestication; the tendency to rely on small sample sizes that reflect physiological dynamics (i.e. in vivo synthesis and utilization) rather than differences arising from modified genomes or novel growing conditions.

Recent research has demonstrated that some geophytes produce morphologically distinct starch granules, and that the measurable characteristics of the largest granules from a sample can be used to distinguish between some species (Louderback et al., 2016) and perhaps even between strains of a single species. This approach has been successfully implemented with other known domesticated geophytes (Manihot esculenta and Ipomoea batatas; Perry, 2002).

While it is not currently grown as a crop, tubers of the Four Corners potato, (Fig. 1, Solanum jamesii Torrey), are known to have been processed on grinding stones at a rock shelter near Escalante, in southern Utah, as early as 10,900 cal B.P. (Louderback and Pavlik, 2017). At that same site are small, extant populations of $S$. jamesii, occupying unusual habitat well beyond the central range of the species (Figure 2; central New Mexico and Arizona), suggesting a history of long-distance transport, if not cultivation. Furthermore, plants from these Escalante populations have been transferred into the gardens of pioneer descendants within the last 20 years and tended continuously. Additional evidence from the Four Corners region suggests that populations of $S$. jamesii growing in and around ancestral Puebloan habitation sites may represent remnants directly descended from previously cultivated plots (Kinder et al., 2017).

Using multiple population sources we test whether tubers and starch granules from propagated, cultivated, and potential cultivar remnant populations of $S$. jamesii show any morphometric differences from those of distant wild populations. We use these data as a teststudy to determine whether tuber and starch morphometrics may be useful in determining the degree of cultivation when examining micro-archaeobotanical remains from potential geophyte cultivars. 


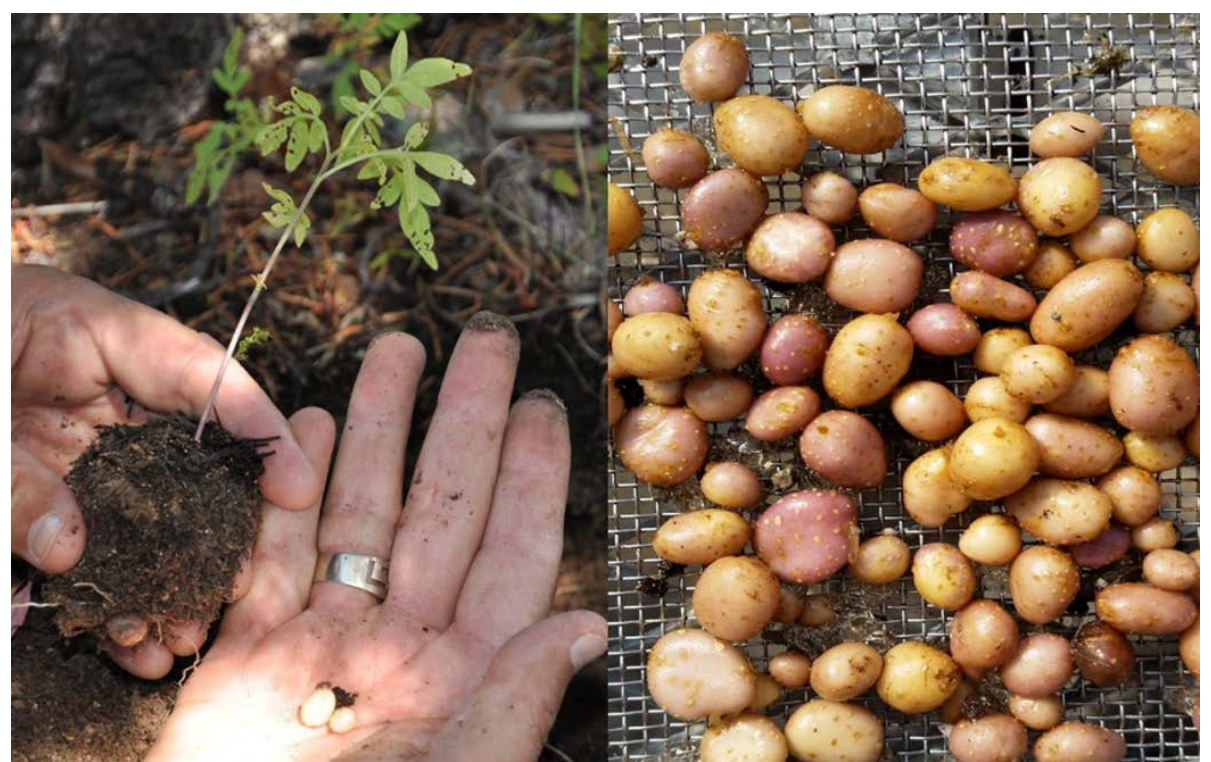

Figure 1. Mature S. jamesii plant from the wild (left) and tubers of propagated S. jamesii, average tuber length is $14.9 \mathrm{~mm}$ (right).

\section{METHODS}

\subsection{Reference materials}

Solanum jamesii is a tuber-forming herbaceous perennial that is active in the summer months and highly productive. This diminutive plant begins forming progeny tubers early in the season and, given ideal growing conditions, can produce up to 500 progeny tubers in one growing season (Louderback and Pavlik, 2017). Perhaps due to its prolific nature and/or high nutrient content, ethnographic and ethnohistoric accounts of $S$. jamesii describe consumption of the species by many Native American groups as well as early pioneers and soldiers (see: Louderback and Pavlik, 2017). The modern range of S. jamesii spans the Four Corners region of southcentral North America, hence the common name, Four Corners potato.

Tuber specimens for this study came from four sources: 1) wild populations in central Arizona and New Mexico [n=60], 2) populations located near or within archaeological sites, termed "archaeological" [ $n=74], 3)$ populations cultivated in private gardens near Escalante, Utah (for $\sim 20$ years) and in Madison, Wisconsin ( 20 years) or in experimental gardens in Farmington, New Mexico (cultivated for $\sim 10$ years), and 4) tubers propagated for two generations in a greenhouse at Red Butte Gardens in Salt Lake City, Utah [ $=19]$.

We collected wild and archaeologically associated tuber specimens from multiple field sites during the summer/fall of 2014, 2015 and 2016 (Figure 2) as part of an ongoing systematic study of the archaeobotanical, genetic, and phytogeographic characteristics of S. jamesii. The archaeological populations are small, isolated and found to be discontinuous across the landscape when sampled along a six mile transect. The wild populations however were large, abundant (thousands of stems) and continuous when sampled along a six mile transect. When 
we came across plants, we conducted an informal archaeological survey in a wide area surrounding the population. Therefore, we are confident in our designations of archaeological and wild populations.

Cultivated specimens grown in Farmington, NM were from the USDA Potato Genebank's core collections of S. jamesii (Bamberg et al., 2016) [ $n=55]$ ). It is not known if the practices of cultivation were equivalent in the private gardens and the USDA plots. We are aware that selection took place in both cases but for different purposes. In the private gardens, interviews suggest a preference for larger tubers, sometimes returned to the garden, sometimes eaten, but irregularly. The USDA however had various research objectives which did include selection for larger tubers, but at the same time selection for other characteristics as well (e.g., freezing tolerance). So it is safe to say that in both cases there was considerable manipulation but for different purposes and different intensities.

The fourth source, propagated tubers, came from tubers collected near Escalante and propagated for two generations in a greenhouse at Red Butte Gardens in Salt Lake City, Utah. These are termed "propagated", but the original material had been archeologically associated. All collected specimens from a given population were included in this study. All propagated tubers grown from a single, second-generation source plant were included in this study.

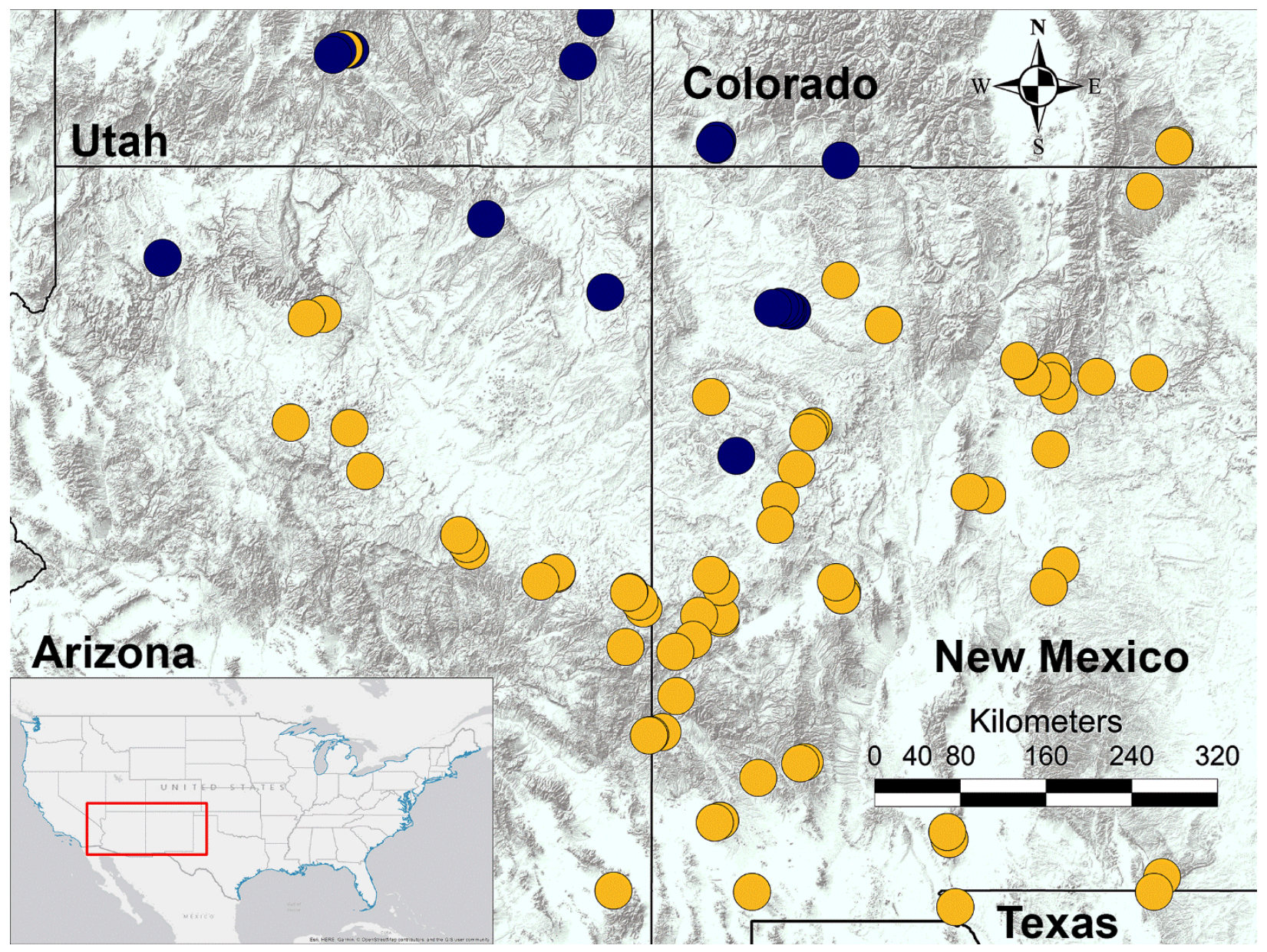


Figure 2. Modern distribution of S. jamesii. Populations associated with archaeological sites are indicated by blue circles, wild populations are shown in yellow.

\subsection{Tuber size analysis}

To determine whether tuber size is related to cultivation, we measured tuber size (length of tuber from apical bud to distal end) for field and propagated sources ( $n=188$ ). Though tuber weight and/or volume may also be a relevant metric, many of the specimens in this study had deflated slightly (perhaps due to water loss) by the time of measurement. Therefore, measurement of length more accurately reflected tuber size, and, likely reflects mass as well. In future studies, weighing tubers (after drying) during field collection is recommended. We applied the Anderson-Darling normality test in the nortest package of $\mathrm{R}$ to measures of tuber length in order to assess skewness and kurtosis within the distributions (R Core Team, 2012; Thode, 2002). Distributions were non-normal both across the entire dataset and within each source, so a generalized linear model (GLM) was constructed using the R stats package (R Core Team, 2012) to test relationships between tuber size and source.

\subsection{Starch granule analysis}

2.3.1 Starch extraction and measurement. We randomly selected a subset of field-collected and propagated S. jamesii specimens $(n=16)$ representing each of the above sources (cultivated, propagated, archaeological and wild) for starch granule measurements (Table 1). Sampled tubers were chosen by drawing a specimen at random from all undecayed/nondeflated collected specimens of a given population/source.

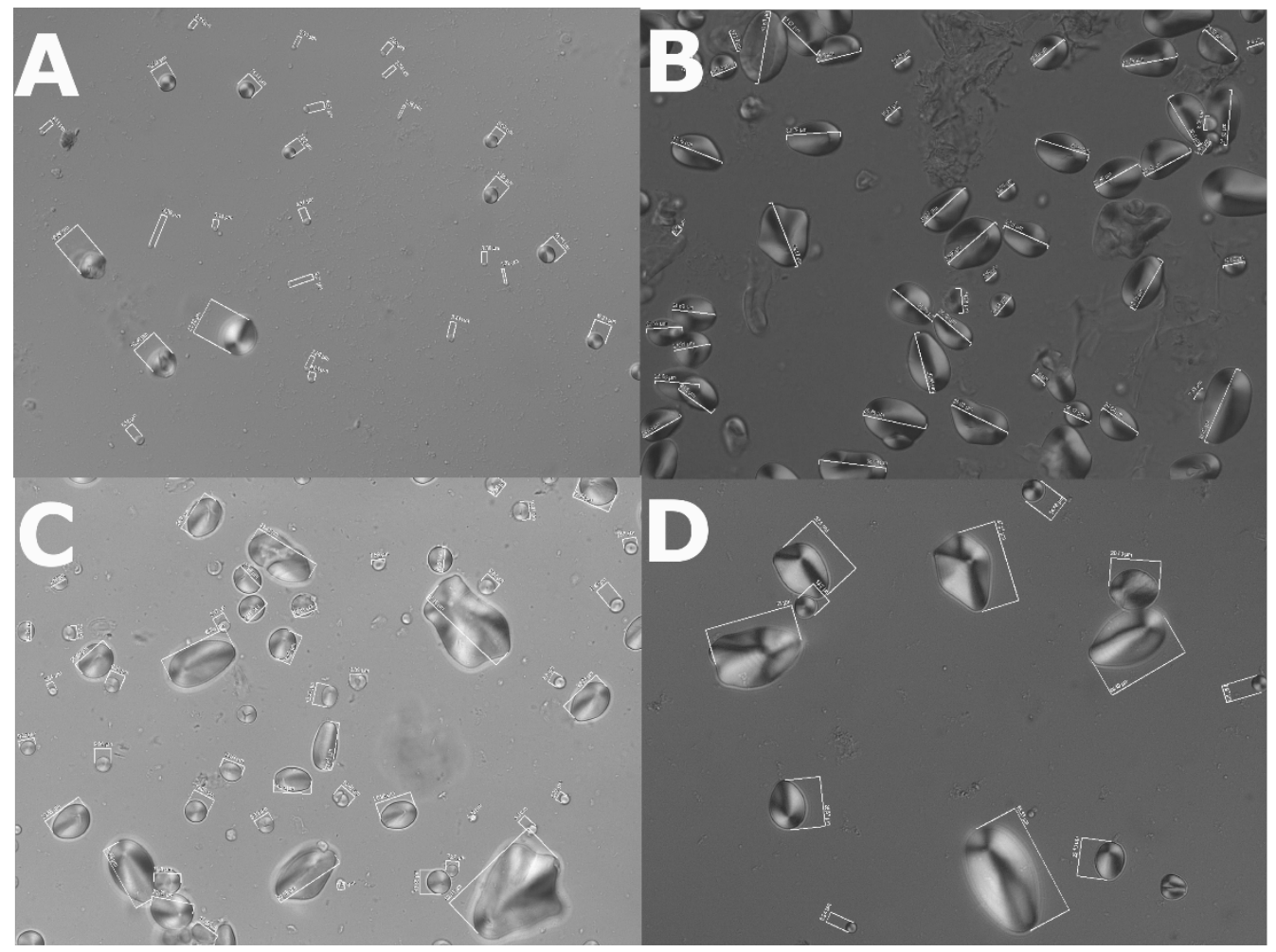


Figure 3. Photographs showing a typical slide image for each of the four sources, (a) F536 - wild, (b) EG1 - archaeological, (c) EG2.2 - propagated, and (d) MEGA76 - cultivated. Each box is approximately 360 microns across.

To isolate starch granules from each specimen for analysis, tubers were bisected with a sterilized blade and the exposed tissue rubbed onto an ethanol-cleaned glass slide. A 50/50 glycerol and $\mathrm{DH}_{2} \mathrm{O}$ solution was then added to the slide surface and mixed with the tissue smear using a sterile pipette. Once mixed, we placed a glass cover slide over the sample, and illuminated in both bright light and cross polarized light using a Zeiss Axioscope 2 transmitted brightfield microscope fitted with polarizing filters and Nomarski optics. A Zeiss HRc digital camera was used to capture images of starch granules at a magnification of $400 x$ (Figure 3 ).

Each slide was positioned beneath the objective and tranches of starch granules were photographed at different locations on the slide using a set of randomly generated $X-Y$ coordinates. In order to minimize bias, all non-compound granules at each position were measured until a sample of 100 was achieved. Once an adequate number of granules were photographed, we measured the maximum length of each starch granule through the hilum using Zen imaging software. This process was conducted independently by two people for each specimen, resulting in the measurement of 200 granules per specimen totaling 3,200 individual granules (data available: Herzog et al., 2018). Length was selected as the primary measure for this study based on previous research indicating that $S$. jamesii starch granules exhibit nonnormal distributions, with smaller granules spherical to slightly ovate in shape and larger granules most often oblong (Louderback et al., 2016). These data suggest expansion is skewed longitudinally. Furthermore, granule length is correlated with other morphological characteristics, such as width, area, circumference (Louderback et al., 2016). For the purposes of this study, other morphological traits were not determined to be useful in making interpopulation distinctions.

Table 1. Tubers selected for starch granule analysis

\begin{tabular}{lllll}
\hline Specimen & Origin & Collection Location & $\begin{array}{l}\text { Date } \\
\text { Collected }\end{array}$ & $\begin{array}{l}\text { Tuber } \\
\text { length (mm) }\end{array}$ \\
\hline BG1 & Cultivated & Madison, Wisconsin & $6 / 2016$ & 15.36 \\
DG1 & Cultivated & Escalante, Utah & $9 / 2015$ & 10.88 \\
DG2 & Cultivated & Escalante, Utah & $9 / 2015$ & 13.44 \\
MEGA076 & Cultivated & Farmington, New Mexico & $11 / 2016$ & 16.5 \\
DD1 & Propagated & Salt Lake City, Utah & $10 / 2015$ & 14.77 \\
DD1.2 & Propagated & Salt Lake City, Utah & $10 / 2015$ & 12.34 \\
EG2.1 & Propagated & Salt Lake City, Utah & $10 / 2015$ & 12.49 \\
EG2.2 & Propagated & Salt Lake City, Utah & $10 / 2015$ & 15.00 \\
LNC1 & Archaeological & L. Navajo Canyon, Colorado & $9 / 2015$ & 8.28 \\
EG1 & Archaeological & Escalante Gorge, Utah & $9 / 2015$ & 8.22 \\
MEVE G & Archaeological & Mesa Verde, Colorado & $9 / 2015$ & 15.07 \\
NP1 & Archaeological & Newspaper Rock, Utah & $9 / 2015$ & 9.31 \\
VR1 & Wild & Vermejo Ranch, New Mexico & $8 / 2015$ & 10.00 \\
F536 & Wild & Feaster, New Mexico & $9 / 2015$ & 10.15
\end{tabular}




\begin{tabular}{lllll} 
PH1 & Wild & Pecos, New Mexico & $8 / 2015$ & 9.35 \\
PC517 & Wild & Picnic Creek, Arizona & $10 / 2015$ & 7.67 \\
\hline
\end{tabular}

2.3.2 Statistical analysis. We generated a series of models to test whether starch granule size (length in microns) was linked to tuber size, and/or source. In order to assess the normality of starch granule length distributions we tested each sample's distributions using the AndersonDarling normality test in the nortest package of $\mathrm{R}$ and measured skew and kurtosis using the moments package in R (R Core Team, 2012; Thode, 2002). All of the populations exhibited nonnormal granule length distributions, mostly skewed toward smaller-sized granules, a pattern observed in previous research (Louderback et al., 2016). When sources were combined, the length distribution for the entire source dataset was also non-normal (Table 3). As such we logtransformed granule length then applied a GLM for hypothesis testing.

Previous research has shown that within S. jamesii it is often only the largest sized granules that exhibit useful surface and structural characteristics for identification (Louderback et al., 2016). Because starch granule length distributions are positively skewed across all sources, we also constructed a GLM to compare the top $20 \%$ of the sample.

\section{RESULTS}

\subsection{Tuber size}

Tuber size progressively increased along a population source gradient from wild to cultivated (Figure 4, Tables 2 and 3). Tubers from the wild population seldom exceed $\sim 16.5 \mathrm{~mm}$, while the largest tubers from cultivated sources could reach $20 \mathrm{~mm}$ or more, a significant difference (Table 2). The largest tubers, on average, came from propagated sources, an outcome likely related to the greater degree of environmental control (water, nutrients, and temperature) exerted during the growing season of these plants. 


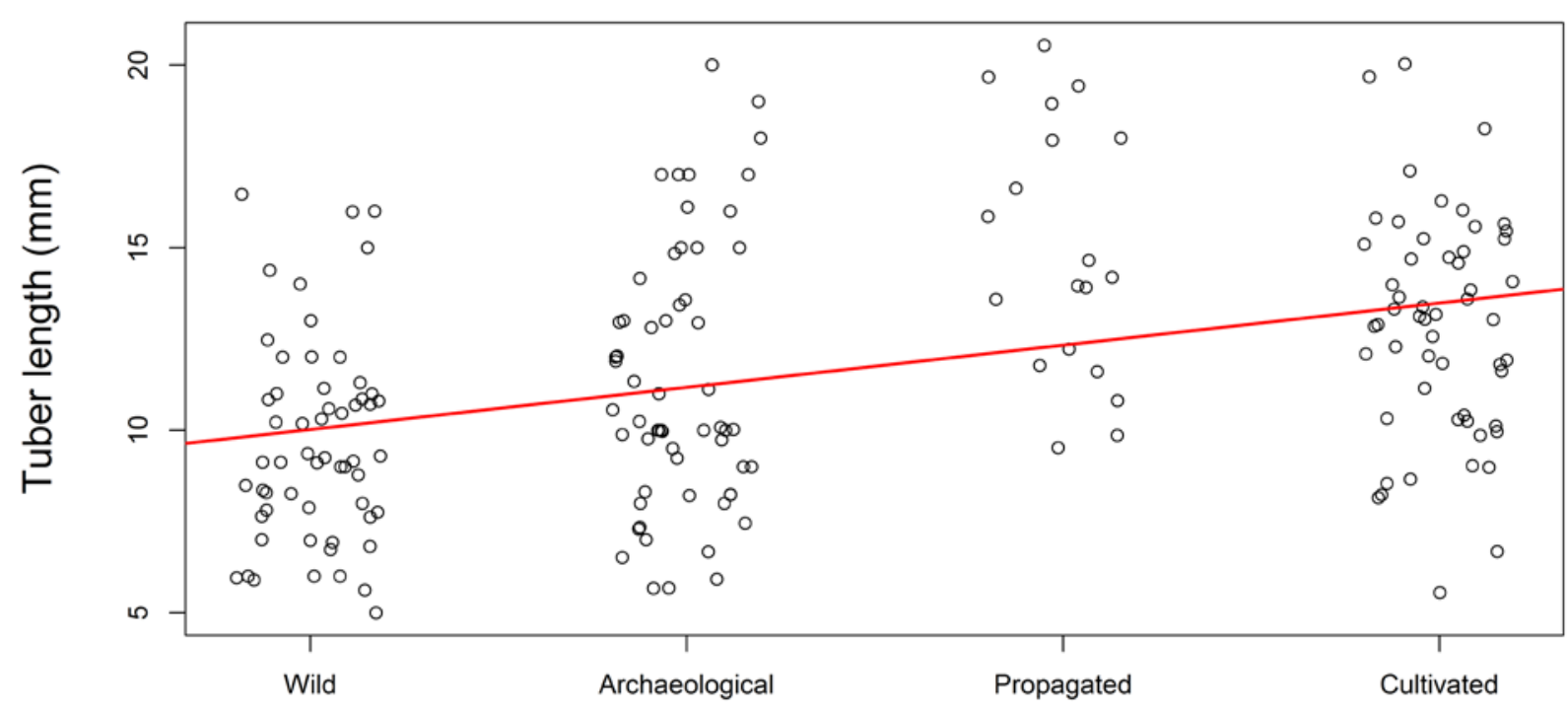

Source

Figure 4. Scatterplot showing the relationship between tuber length $(\mathrm{mm})$ and source population. Black dots represent raw measurements for individual tubers. The red line represents the parameter estimates of the GLM model, with the intercept as the intercept parameter $(8.871 ; p \geq 0 ; 95 \%$ Confidence Interval (CI) 7.82 - 9.91) and slope as source (1.153; $p \geq 0 ; 95 \%$ Confidence Interval (CI) 0.76 1.54).

Table 2. GLMs for relationships between tuber and granule size and population sources.

\begin{tabular}{llcll}
\hline Model & Variable & Estimate & SE of Estimate & $\operatorname{Pr}(>|\mathrm{t}|)$ \\
\hline Tuber length & Intercept & 8.871 & 0.535 & $<.001^{* * *}$ \\
& Source & 1.153 & 0.201 & $<.001^{* * *}$ \\
& & & & \\
Starch granule length & Intercept & 1.037 & 0.022 & $<.001^{* * *}$ \\
& Source & 0.044 & 0.006 & $<.001^{* * *}$ \\
& Tuber size & -0.003 & 0.002 & 0.201 \\
& & & & \\
Starch granule length (top 20\%) & Intercept & 1.351 & 0.018 & $<.001^{* * *}$ \\
& Source & 0.047 & 0.006 & $<.001^{* * *}$ \\
& Tuber size & 0.003 & 0.002 & 0.204 \\
\hline
\end{tabular}

\subsection{Starch morphology}

Starch granules from wild populations exhibited the smallest mean length size, while those from cultivated source populations were largest (Table 3). The starch granule distributions from wild populations contain relatively few outliers, reflecting the low degree of kurtosis, while all other populations are leptokurtic indicating the presence of outliers influencing the overall shape of the distributions (Table 3). Granule length distributions are negatively skewed across each of the sources, weighted by an abundance of smaller sized granules (Table 3).

In the GLM model, log-transformed granule length was positively correlated with source 
population but not tuber size (Table 2, Figure 5). Therefore, regardless of tuber size, starch granules from the cultivated sources are larger than those from all other source categories.
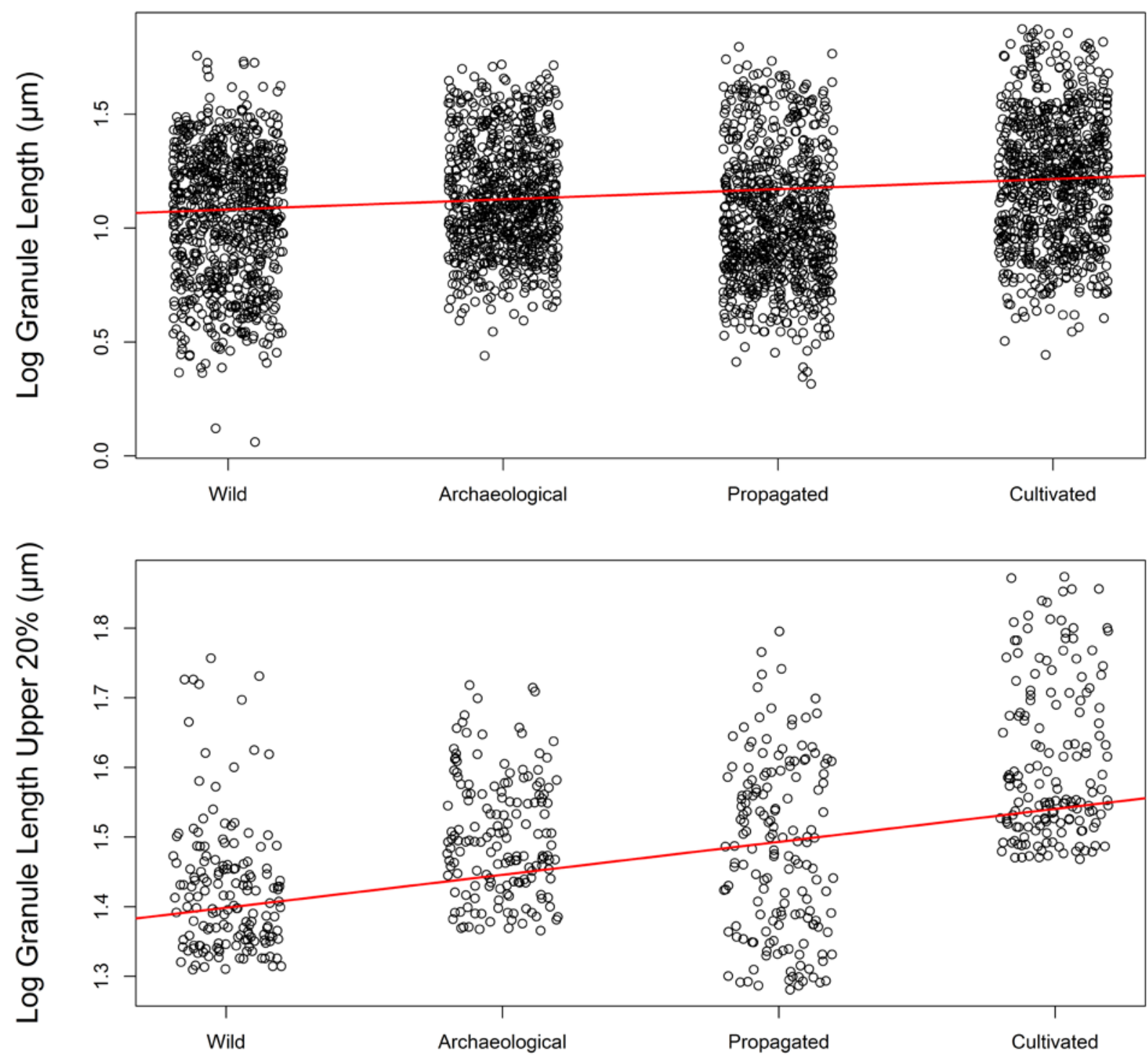

Source

Figure 5. (Above) Scatterplot showing the relationship between log-transformed starch granule length $(\mu \mathrm{m})$ and source population. (Below) Scatterplot showing the relationship between the upper $20 \%$ of log-transformed starch granule lengths $(\mu \mathrm{m})$ and source population. Black dots represent measurements for individual starch granules (above: $n=800$ per source; below: $n=160$ per source). Red lines represent the parameter estimates of the GLM model holding tuber size constant (above: Intercept 1.04, $\mathrm{p} \geq 0$, 95\% Confidence Interval ( $\mathrm{Cl}) 0.99-1.08$; slope as source, $0.06, \mathrm{p} \geq 0,95 \% \mathrm{Cl} 0.03-0.06$. below: Intercept parameter $1.35, \mathrm{p} \geq 0,95 \% \mathrm{Cl} 1.32-1.38$; slope as source $0.05, \mathrm{p} \geq 0,95 \% \mathrm{Cl} 0.04-0.06$ ). (granule length top $20 \%$ source + tuber size), differences in granule length among sources 
1 became much more pronounced, and the statistical relationships stronger (Table 2).

2 Additionally, potentially diagnostic structural features, such as the narrow, unbranched

3 longitudinal fissure that is characteristic of this species, are much more common among

4 granules within the top 10 and $20 \%$ of samples in S. jamesii (Louderback et al., 2016).

5

Table 3. Tuber length and starch granule length across source populations.

\begin{tabular}{llrrrr}
\hline Sample & Cultivation condition & Mean & Median & Kurtosis & Skewness \\
\hline Tuber length $(\mathrm{mm})$ & Wild & 9.642 & 9.150 & 2.979 & 0.627 \\
& Archaeological & 11.320 & 10.080 & 2.451 & 0.517 \\
& $\begin{array}{l}\text { Propagated } \\
\text { Cultivated }\end{array}$ & 14.900 & 14.190 & 1.787 & 0.095 \\
& & 12.84 & 13.040 & 2.921 & -0.034 \\
& Wild & & & & \\
Log starch granule & & 1.053 & 1.093 & 2.480 & -0.321 \\
length $(\mu \mathrm{m})$ & Archaeological & 1.134 & 1.108 & 2.371 & 0.207 \\
& Propagated & 1.042 & 1.006 & 2.607 & 0.346 \\
& Cultivated & 1.216 & 1.225 & 2.575 & 0.371 \\
& & & & & \\
Raw starch granule & Wild & 13.88 & 12.39 & 5.521 & 1.228 \\
length $(\mu \mathrm{m})$ & & & & \\
& Archaeological & 16.03 & 12.83 & 4.01 & 1.251 \\
& Propagated & 13.839 & 10.135 & 5.555 & 1.689 \\
& Cultivated & 20.170 & 16.81 & 5.260 & 1.474 \\
\hline
\end{tabular}

\section{DISCUSSION}

The suite of morphological changes apparent in the seeds of domesticated plant species, collectively termed 'the adaptive or domestication syndrome', has been well-documented (Hammer, 1984). However, among domesticated geophytes that are vegetatively propagated (i.e. cloned), populations tend to be closely related and often possess minor genetic differences (Fuller et al., 2014; Zohary, 2004). Consequently, there is no widely described 'adaptive syndrome' for geophyte domesticates, especially in the absence of archaeological plant material. Could tuber and starch granule characteristics be indicative of early stage domestication?

In the present study, tubers from wild populations were, on average, three millimeters smaller than those originating from cultivated plots. These data suggest that tuber size could be used as an index of degree of cultivation when compared to tubers from wild populations. However, vegetative materials from tuberous food sources are not often recovered from archaeological deposits. When they are, they are commonly fragmentary and desiccated, preventing any straightforward assessment of original size.

In lieu of preserved vegetal material, other means of detection are necessary for identifying pre-domesticate root crops in the archaeological record. Past research has highlighted the 
ability of starch granule analysis to detect the presence of geophyte residues on stone tools despite their absence in macrobotanical assemblages (e.g. Dickau et al., 2007; Herzog and Lawlor, 2016; Louderback and Pavlik, 2017; Messner, 2011; Perry, 2004, 2002). Therefore, archaeological starch granule assemblages may provide an avenue for identifying predomesticates and cultivars (i.e., Perry, 2002). Indeed, starch granules from cultivated populations were larger than from wild populations, especially those in the top $20 \%$ of the sample distribution. No starch granule from a wild population exceeded 60 microns in length and only $3.5 \%$ of the granules exceeded 50 microns. However, $20 \%$ of the granules in the cultivated populations exceeded 50 microns. As such, recovered archaeological starch granules >50-60 microns may be an indicator of cultivation in S. jamesii.

Increases in tuber and granule size may be an outcome of genetically driven increases in carbon fixation, sugar transport and starch synthesis. In studies of South American potato species, advantageous traits appear to have been achieved via distinct pathways reliant on regional adaptation rather than conserved developmental processes (Hardigan et al., 2017). Work on the potato genome has identified a set of population-specific genes in $S$. tuberosum cultivars that suggest selection for traits related to enlarged tubers, increase in leaf carbon fixation and transport, glycoalkaloid reduction, adaptation to long-day photoperiod, and reduced sexual fertility (Hardigan et al., 2017). We fully expect the same to be found for the North American S. jamesii. Preliminary data demonstrate a range of tuber glycoalkaloid content across S. jamesii populations, suggesting alternate pressures at different locations (Louderback and Pavlik, 2017).

Alternatively, tuber and starch granule size are also known to be linked to environmental conditions (Thitisaksakul et al. 2013). For example, under drought conditions starch granules are significantly smaller than those of well-watered control plants (Brooks et al., 1982). The differences in tuber and granule size measured in the present study cannot exclusively be assigned to genetic differences among source populations. Long-term manipulation (as in wild or archaeological settings) or intensive, purposeful selection (as in an experimental garden) would be required for the differences to have a genetic basis. Short-term manipulation (as in a greenhouse) would more likely result in phenotypic differences, especially when water and nutrient resources are provided and carbon gain is maximized. Whether these differences have a genotypic or phenotypic basis, human intervention appears likely to have shaped changes in potato tuber micro and macromorphology, including among populations of S. jamesii.

While these results provide a platform for the use of starch granule morphometrics to evaluate cultivation practices in the past, we urge caution in this approach. Results presented here apply only to $S$. jamesii and cannot be generalized as yet for other species. An adequate assessment of wild population granule size is necessary before analyses of archaeological assemblages can be undertaken. In addition, we find it inadvisable to make determinations of cultivation status based on the presence and morphology of single granules or even limited assemblages. It is difficult to estimate at what size an archaeological assemblage might be large enough to assess these effects. It is clear that, at least in the case of S. jamesii, a minimum of $20 \%$ of the total archaeological assemblage should be over 50 microns in size to consider cultivation a 
possibility. In a sample of only 10 granules, such a conclusion would obviously be tenuous. Ideally, starch analyses would work with hundreds of archaeological granules and be considered in tandem with other archaeological and/or ecological indications of cultivation.

While it is still unknown whether extant populations of $S$. jamesii associated with archaeological sites in Utah and New Mexico are remnant populations derived from cultivated strains, these produced both larger tubers and larger starch granules than those with no archaeological association - suggesting some form of human manipulation in the past. Another clue to anthropogenic interaction is the distribution of some archaeologically associated populations. Populations located furthest from the present range of S. jamesii (Hijmans et al., 2002) are often associated with archaeological sites, suggesting transport and/or management by human groups (Bamberg et al., 2016; Kinder et al., 2017; Louderback and Pavlik, 2017). Further study, incorporating more populations across the entire range of the species are necessary to test this hypothesis and to develop the chronology of wild plant domestication in western North America.

\section{ACKNOWLEDGEMENTS}

We would like to thank John Bamberg, Chico Fernandez, Renee Sauer, Jesse Schartner (USDA Potato Genebank, Madison Wisconsin), David Kinder (Northern Ohio University) and DeLane Griffin (Escalante, Utah) for providing tubers from cultivated and archaeological populations for this study. All other collections were made under Permit 6840 / UT-933, issued by the USDI Bureau of Land Management and Permit UT-13-033-02B, issued by Grand Staircase-Escalante National Monument, to Red Butte Garden and Arboretum. Avery Uslaner produced the Figure 2 map. We are grateful for the feedback and comments of two anonymous reviewers on earlier versions of the manuscript. We would also like to thank Nathan Goodale for helpful suggestions and insights. This research did not receive any specific grant from funding agencies in the public, commercial, or not-for-profit sectors.

\section{REFERENCES}

Asch, D., Asch, N., 1985. Prehistoric Plant Cultivation in West Central Illinois, in: Ford, R.I. (Ed.), Prehistoric Food Production in North America, Anthropological Papers. University of Michigan, Michigan, pp. 149-203.

Ball, T., Chandler-Ezell, K., Dickau, R., Duncan, N., Hart, T. C., Iriarte, J., Lentfer, C., Logan, A., Lu, H., Madella, M., Pearsall, D.M., Piperno, D.R., Rosen, A., Vrydaghs, L., Weisskopf, A., Zhang, J., 2016. Phytoliths as a tool for investigations of agricultural origins and dispersals around the world. Journal of Archaeological Science, 68, 32-45. https://doi.org/10.1016/j.jas.2015.08.010

Bamberg, J., Del Rio, A.H., Kinder, D., Louderback, L., Pavlik, B., \& Fernandez, C., 2016. Core collections of potato (Solanum) species native to the USA. American journal of potato research, 93(6), 564-571. https://doi.org/10.1007/s12230-016-9536-2

Blackman, B. K., Scascitelli, M., Kane, N. C., Luton, H. H., Rasmussen, D. A., Bye, R. A., Lentz, D.L., \& Rieseberg, L. H., 2011. Sunflower domestication alleles support single domestication 
center in eastern North America. Proceedings of the National Academy of Sciences, 108(34), 14360-14365. https://doi.org/10.1073/pnas.1104853108

Brooks, A., Jenner, C.F. and Aspinall, D., 1982. Effects of water deficit on endosperm starch granules and on grain physiology of wheat and barley. Functional Plant Biology, 9(4), pp.423-436.

Bruno, M.C., Whitehead, W.T., 2003. Chenopodium cultivation and Formative Period agriculture at Chiripa, Bolivia. Lat. Am. Antiq. 14, 339-355. https://doi:10.2307/3557564

Del Rio, A.H., Bamberg, J.B., 2003. The effect of genebank seed increase on the genetics of recently collected potato (Solanum) germplasm. American journal of potato research, 80(3), 215-218. https://doi.org/10.1007/BF02855693

Dickau, R., Ranere, A.J., Cooke, R.G., 2007. Starch granule evidence for the preceramic dispersals of maize and root crops into tropical dry and humid forests of Panama. Proc. Natl. Acad. Sci. 104, 3651-3656. https://doi.org/10.1073/pnas.0611605104

Doebley, J.F., Gaut, B.S., Smith, B.D., 2006. The molecular genetics of crop domestication. Cell 127, 1309-1321. https://doi.org/10.1016/i.cell.2006.12.006

Fritz, G.J., Smith, B.D., 1988. Old collections and new technology: Documenting the domestication of Chenopodium in eastern North America. Midcont. J. Archaeol. 13, 327. http://www.jstor.org/stable/20708263

Fritz, G. J., Adams, K.R., Rice, G.E., \& Czarzasty, J.L., 2009. Evidence for domesticated Amaranth from a sedentary period Hohokam house floor at Las Canopas. Kiva 74(4):393-419. https://doi: 10.1179/kiv.2009.74.4.002

Fuller, D.Q., Denham, T., Arroyo-Kalin, M., Lucas, L., Stevens, C.J., Qin, L., Allaby, R.G., Purugganan, M.D., 2014. Convergent evolution and parallelism in plant domestication revealed by an expanding archaeological record. Proc. Natl. Acad. Sci. 111, 6147-6152. https://doi:10.1073/pnas.1308937110

Hammer, K., 1984. Das domestikationssyndrom. Kult. 32, 11-34. https://doi.org/10.1007/BF02098682

Hardigan, M.A., Laimbeer, F.P.E., Newton, L., Crisovan, E., Hamilton, J.P., Vaillancourt, B., Wiegert-Rininger, K., Wood, J.C., Douches, D.S., Farré, E.M. and Veilleux, R.E., 2017. Genome diversity of tuber-bearing Solanum uncovers complex evolutionary history and targets of domestication in the cultivated potato. Proceedings of the National Academy of Sciences, 114(46), pp.E9999-E10008. https://doi.org/10.1073/pnas.1714380114

Harter, A. V., Gardner, K. A., Falush, D., Lentz, D. L., Bye, R. A., \& Rieseberg, L. H., 2004. Origin of extant domesticated sunflowers in eastern North America. Nature, 430(6996), 201. https://doi:10.1038/nature02710

Heiser Jr, C.B., 1985. Some botanical considerations of the early domesticated plants north of Mexico in prehistoric food production in North America. Anthropol. Pap. 57-72.

Herzog, N.M., Lawlor, A., 2016. Reevaluating diet and technology in the Archaic Great Basin using Hogup Cave starch assemblages. Am. Antiq. 81 (4), 664-681. https://doi.org/10.1017/S0002731600101027

Herzog, N.M., Louderback, L.A., Pavlik, B.M., 2018. Starch granule length data for effects of cultivation on tuber and starch granule morphometrics of Solanum jamesii and implications for interpretation of the archaeological record 
Hijmans, R.J., Spooner, D.M., Salas, A.R., Guarino, L., de la Cruz, J., 2002. Atlas of Wild Potatoes, Systematic and ecogeographic studies on crop genepools, 10. International Plant Genetic Resources Institute, Rome.

Holst, I., Moreno, J.E., Piperno, D.R., 2007. Identification of teosinte, maize, and Tripsacum in Mesoamerica by using pollen, starch granules, and phytoliths. Proc. Natl. Acad. Sci. 104, 17608-17613. https://doi.org/10.1073/pnas.0708736104

Kinder, D. H., Adams, K. R., \& Wilson, H. J., 2017. Solanum jamesii: Evidence for cultivation of wild potato tubers by ancestral Puebloan groups. Journal of Ethnobiology, 37(2), 218240. https://doi.org/10.2993/0278-0771-37.2.218

Kraft, K. H., Brown, C. H., Nabhan, G. P., Luedeling, E., Ruiz, J. D. J. L., d’Eeckenbrugge, G. C., Hijmans, R. J., \& Gepts, P., 2014. Multiple lines of evidence for the origin of domesticated chili pepper, Capsicum annuum, in Mexico. Proceedings of the National Academy of Sciences, 111(17), 6165-6170. https://doi.org/10.1073/pnas.1308933111

Liu, L., Ma, S., \& Cui, J., 2014. Identification of starch granules using a two-step identification method. Journal of Archaeological Science, 52, 421-427. https://doi.org/10.1016/j.jas.2014.09.008

Louderback, L.A., Herzog, N.M., Pavlik, B.M., 2016. Identification of starch granules from wild food plants in arid western North America. Starch - Stärke 68, 1-7. https://doi.org/10.1002/star.201600167

Louderback, L. A., \& Pavlik, B. M. 2017. Starch granule evidence for the earliest potato use in North America. Proceedings of the National Academy of Sciences, 114(29), 7606-7610. https://doi.org/10.1073/pnas.1705540114

Messner, T.C., 2011. Acorns and Bitter Roots: Starch Granule Research in the Prehistoric Eastern Woodlands. University Alabama Press, Tuscaloosa.

Meyer, R.S. and Purugganan, M.D., 2013. Evolution of crop species: genetics of domestication and diversification. Nature reviews genetics, 14(12), p.840.

Pearsall, D. M. (1978). Phytolith analysis of archeological soils: evidence for maize cultivation in formative Ecuador. Science, 199(4325), 177-178. https://DOI: 10.1126/science.199.4325.177

Perry, L., 2004. Starch analyses reveal the relationship between tool type and function: an example from the Orinoco valley of Venezuela. J. Archaeol. Sci. 31, 1069-1081. https://doi.org/10.1016/j.jas.2004.01.002

Perry, L., 2002. Starch granule size and the domestication of manioc (Manihot esculenta) and sweet potato (Ipomoea batatas). Econ. Bot. 56, 335-349. https://doi:10.1663/00130001(2002)056[0335:SGSATD]2.0.CO;2

Perry, L., Dickau, R., Zarrillo, S., Holst, I., Pearsall, D.M., Piperno, D.R., Berman, M.J., Cooke, R.G., Rademaker, K., Ranere, A.J., Raymond, J.S., Sandweiss, D.H., Scaramelli, F., Tarble, K., Zeidler, J.A., 2007. Starch fossils and the domestication and dispersal of chili peppers (Capsicum spp. L.) in the Americas. Science 315, $986-988$. https://DOI:10.1126/science.1136914

Piperno, D. R., Stothert, K.E., 2003. Phytolith evidence for early Holocene Cucurbita domestication in southwest Ecuador. Science, 299(5609), 1054-1057. https:// DOI: 10.1126/science.1080365 
Piperno, D.R., Dillehay, T.D., 2008. Starch granules on human teeth reveal early broad crop diet in northern Peru. Proc. Natl. Acad. Sci. 105, $19622-19627$. https://doi:10.1073/pnas.0808752105

Piperno, D.R., Ranere, A.J., Holst, I., Iriarte, J., Dickau, R., 2009. Starch granule and phytolith evidence for early ninth millennium B.P. maize from the Central Balsas River Valley, Mexico. Proc. Natl. Acad. Sci. 106, 5019-5024. https://doi:10.1073/pnas.0812525106

R Core Team, 2012. R: A language and environment for statistical computing. R Foundation for Statistical Computing: Vienna, Austria.

Sanjur, O.I., Piperno, D.R., Andres, T.C., Wessel-Beaver, L., 2002. Phylogenetic relationships among domesticated and wild species of Cucurbita (Cucurbitaceae) inferred from a mitochondrial gene: Implications for crop plant evolution and areas of origin. Proc. Natl. Acad. Sci. 99, 535-540. https://doi.org/10.1073/pnas.012577299

Smith, B.D., 2006a. Seed size increase as a marker of domestication in squash (Cucurbita pepo), in: Zeder, M.A., Bradley, D.G., Emshwiller, E., Smith, B.D. (Eds.), Documenting Domestication: New Genetic and Archaeological Paradigms. University of California Press, Berkeley, pp. 25-31.

Smith, B.D., 2006b. Eastern North America as an independent center of plant domestication. Proc. Natl. Acad. Sci. 103, 12223-12228. https://doi:10.1073/pnas.0604335103

Thitisaksakul, M., Jiménez, R.C., Arias, M.C. and Beckles, D.M., 2012. Effects of environmental factors on cereal starch biosynthesis and composition. Journal of Cereal Science, 56(1), pp.67-80.

Thode, H.C., 2002. Testing For Normality. CRC Press.

Van Heerwaarden, J., Doebley, J., Briggs, W. H., Glaubitz, J. C., Goodman, M. M., Gonzalez, J. D. J. S., \& Ross-Ibarra, J. (2011). Genetic signals of origin, spread, and introgression in a large sample of maize landraces. Proceedings of the National Academy of Sciences, 108(3), 1088-1092. https://doi.org/10.1073/pnas.1013011108

Zarrillo, S., Pearsall, D.M., Raymond, J.S., Tisdale, M.A., Quon, D.J., 2008. Directly dated starch residues document early formative maize (Zea mays L.) in tropical Ecuador. Proc. Natl. Acad. Sci. 105, 5006 -5011. https://doi:10.1073/pnas.0800894105

Zeder, M.A., Emshwiller, E., Smith, B.D., \& Bradley, D.G., 2006. Documenting domestication: the intersection of genetics and archaeology. TRENDS in Genetics, 22(3), 139-155. https://doi.org/10.1016/i.tig.2006.01.007 